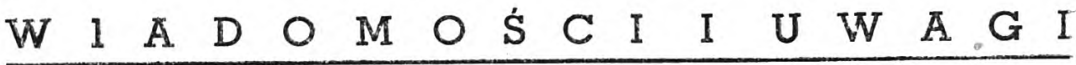

\section{DEKRET OGÓLNY SW. KONGREGACJI OBRZĘDOW \\ o odnowieniu porządku nabożeństw podczas Wielkiego Tygodnia (Maxima redemptionis nostrae mysteria)}

Największe naszego zbawienia tajemnice, mianowicie Męki, Śmiercí i Zmartwychwstania Pana N. J. Chr, już od czasów apostolskich starał się Kościół Matka nasza, corocznie w szczególniejszy sposób wspominać i czcić. Naprzód przez osobny okres trzech dni obchodzono najważniejsze tych tajemnic chwile, mianowicie Chrystusa ,ulkrzyżowanego, pogrzebanego i zmartwychwstalego" (S. Augustinus, Ep. 55, 14); wnet dołączyło się także uroczyste wspomnienie ustanowienia Najśw. Eucharystii, wreszcie w niedzielę, która bezpośrednio Mękę wyprzedza. przybył liturgiczny obchód triumfalnego wjazdu Pana Naszego, Króla mesjańskiego, do miasta świętego; tak powstał szczególny tydzień liturgiczny, który z powodu wyższości obchodzonych tajemnic został nazwany świętym (Wielkim) i wzbogacony wspaniałymi i pobożnymi obrzędami.

Olbrzędy te były odprawiane w tych samych dniach i w tych samych godzinach tych dni, w których te najświętsze tajemnice się wydarzyły. I tak; pamiątkę ustanowienia Najśw. Eucharystii obchodzono w czwartek, wieczorem, uroczystą Msza św. Wieczerzy Pańskiej; w piątek zaś w godzinach popołudniowych urządzano osobne nabożeństwo liturgiczne poświęcone Męce i Śmierci Pańskiej; wreszcie w sobotę wieczorem rozpoczynala się uroczysta wigilia, która kończyła się dnia następnego rano radością Zmartwychwstania.

Natomiast $w$ średnich wiekach zaczęto $z$ róznych przyczyn czas tych liturgicznych czynności tak uprzedzać, że pod koniec średniowiecza wszystkie te liturgiczne uroczystości przeniesiono na godziny poranne, nie bez szkody dla liturgicznego ich znaczenia, i nie bez zamieszania między opowiadaniem ewangelii, a odnośnymi tekstami liturgicznymi. W szczególności skutkiem tego liturgia wigilii paschalnej, oderwana od swej nocnej podstawy, straciła swoją naturaina przejrzystość, a także znaczenie słów i symbolów. Ponadto dzień wielkiej soboty zapełniony przedwczesną radością paschalną, utracił swój właściwy charakter ża-. łobny pamiątki Pańskiego pogrzebu. 
W bliższych nam czasach dołączyła się $w$ końcu jeszcze inna zmiana $\mathrm{i}$ to $\mathrm{z}$ duszpasterskiego punktu widzenia największa. Mianowicie dawniej czwartek, piątek i sobota Wielkiego Tygodnia były obchodzone przez wiele wieków jako święta uroczyste, w tym oczywiście celu, by cały lud chrześcijański, wolny w tych dniach od prac służebnych, mógł brać udział w obrzędach tych świętych dni; tymczasem w ciągu wieku XVII Papieże widzieli się zmuszeni zmnieiszyé liczbe świąi uroczystych z powodu zmienionych warunków życia społecznego. I tak Urban VIII konstytucja apostolską ,Universa per orbem“ z 24. IX. 1642 r., zmuszony był zaliczyć okres trzech dni W. Tygodnia do szeregu dni powszednich, a nie świąt uroczystych.

Skutkiem tego udział wiernych w tych świętych obrzędach siłą konieczności zmniejszył się, a to przede wszystkim z tej przyczyny, że ich odprawianie przeniesiono już od dawna na godziny poranne, w których powszechnie na całym świecie zwykle czynne sa szkoły, warsztaty pracy i zajęcia publiezne wszelkiego rodzaju. Dlatego w rzeczywistości, jak prawie powszechne doświadczenie uczy, uroczyste te i poważne trzech dni liturgiczne nabożeństwa duchowieństwo zwykło odprawiać we wnętrzach kościołów prawie pustych.

I nad tym trzeba bardzo ubolewać. Albowiem obrzędy liturgiczne Wielkiego Tygodnia odznaczają się nie tylko szczególną swoją godnościa, lecz i szczególną mocą sakramentalną i skutecznością dla ożywienia życia chrześcijańskiego, i nie można ich zastąpic przez te nabożeństwa, które się zwykło nazywać pozaliturgicznymi, a które w okresie trzech dni odbywają się w godzinach popołudniowych.

$\mathrm{Z}$ tych powodów doświadczeni liturgiści, kapłani zajęci duszpasterstwem, a przede wszystkim sami biskupi zwracali się w ostatnich latach do Stolicy Świętej z prośbami, aby obrzędy liturgiczne świętych trzech dni Wielkiego Tygodnia zostały przywrócone, jak niegdyś było, na godziny popołudniowe, w tej oczywiście myśli, by łatwiej było wszystkim wiernym brać w tych obrzędach udział.

Rozważywszy pilnie tę sprawę, Ojciec św. Pius XII już w r. 1951 wznowił liturgie świętej wigilii paschalnej, a to do uznania Ordynariuszów diecezji i na próbę.

Skoro więc ta próba spotkała się powszechnie z powodzeniem, jak to wynika ze sprawozdań wielkiej liczby Ordynariuszów diecezji przesłanych Stolicy świętej, - skoro ci Ordynariusze nie omieszkali przy tym ponowić próśb, by podobnie jak dla wigilii paschalnej, także i dla innych dni Wielkiego Tygodnia dokonano tego samego liturgicznego odnowienia przez przywrócenie świętych obrzędów na godziny wieczorne, - wreszcie biorąc pod uwagę, że Isze wieczorne, przewidziane konstytucją apostolską "Christus Dominus" z 6. I. 1953 r., wszędzie odprawiaja się przy większym udziale wiernych; mając to wszystko przed oczyma Ojciec św. Pius XII nakazał, aby Komisja dla odnowienia liturgii przez tegoż Papieża ustanowiona tę sprawę o wznowieniu porządku nabożeństw Wiel. 
kiego Tygodnia zbadala i zaproponowała wnioski. Otrzymawszy je Ojciec św. Pius XII postanowił, aby cała ta sprawa ze względu na swą wage była poddana jeszcze szczególnemu zbadaniu przez Ks. Ks. Kardynałów św. Kongregacji Obrzędów.

Księża Kardynałowie na nadzwyczajnym zebraniu dn. 19. VII. b. r. w Watykanie rozważywszy pilnie tę sprawę uchwalili jednogłośnie, że należy zatwierdzić wznowienie porządku Wielkiego Tygodnia i rozkazać jego wykonanie. o ile zgodzi się na to Ojciec św.

Po przedstawieniı tych wniosków szczególowo Ojcu św. przez podpisanego Kardynała Prefekta, Jego Swiątobliwość raczył zatwierdzić uchwały Księży Kardynałów.

Dlatego św. Kongregacja. Obrzędów na podstawie szczególnego zlecenia Ojca św. Papieża Piusa XII zarządza, co następuje:

\section{Zarządzenie o wznowieniu porzadku nabożeństw w W. Tygociniu}

1) Ci, których obowiązuje obrządek rzymski, na przyszłość winni zachowywać Porządek W. Tygodnia wznowiony, a w urzędowym wydaniu Drukarni Watykańskiej zawarty. Ci, kłórych obowiązuje inny rytuał łaciński, winni zachowywać tylko czas odprawiania liturgicznych nabożenstw ustanowionych w nowym Porządku.

2) Ten nowy Porządek należy zachowywać począwszy od 25. III. niedzieli II Męki Pańskiej czyli Palmowej, roku 1956.

3) Przez cały W. Tydzień wykluczone są wszelkie kommemoracje, a we Mszy zakazuje się także kollekt z jakiegokolwiek tytułu nakazanych.

\section{Godzina odpowiednia dla odprawiania liturgii W. Tygodnia}

Brewiarz.

4) W niedzielę II Męki Pańskiej czyli Palmową, w poniedziałek, wtorek i środę W. Tygodnia odmawia się brewiarz w godzinach zwykłych.

5) W okresie trzech dni, tj.: w czwartek Wieczerzy Pańskiej, w piątek. Męki i Śmierci Pańskiej i w Wielką Sobotę, jeśli brewiarz odmawia się W ,chórze“, lub „wspólnie“, należy zachować następujące przepisy:

Matutinum i Laudes nie antycypuje się poprzedniego wieczoru, lecz odmawia się je rano w godzinie odpowiedniej. W kościołach zaś katedralnych, w których w W. Czwartek odprawia się rano IMsza św. dla poświęcenia świętych Olejów. Matutinum i Laudes moga być antycypowane wieczorem.

Horae minores mówi się $w$ godzinach odpowiednich.

Nieszpory w W. Czwartek i Piątek opuszcza się, ponieważ ich miejsce zajmują obrzędy liturgiczne pierwszorzędne dla tych dni. Natomiast w W. Sobotę mówi się je po południu w godzinie zwykłej.

Completorium w W. Czwartek i Piątck odmawia się po wieczornych obrzędach liturgicznych, natomiast opuszcza się je w W. Sobotę. 
Przy odmawianiu prywatnym w okresie tych trzech dni wszystkie godziny kanoniczne (brewiarza) winny być odmawiane według rubryk.

Msza lub pierwszorzędne naboż. liturgiczne.

3) W niedzielę II Mięki Pańskiej uroczyste poświęcenie palm i procesja odbywaja sie rano w godzinie zwykłej; w chórze jednak po Tercji.

7) W W. Czwartek Wierzeczy Pańskiej Mszę św. dla poświęcenia Olejów świętych odprawia się po Tercji. A zaś Mszę Wieczerzy Pańskiej należy odprawić wieczorem $w$ godzinie najodpowiedniejszej, jednal nie przed godzina piątą po południu, ani po godzinie ósmej.

8) W W. Piątek Mlęki i Smierci Pańsłsiej uroczyste nabożeństwo litur-giczne odprawia się w godzinach popołudniowych, a mianowicie koło: godziny trzeciej; jeśli jeđnak wzgląd duszpasterski tak radzi, wolno wybrać godzinę późniejszą, jednak nie późniejszą od godziny szóstej.

9) Uroczystą wigilię paschalną należy odprawiać w godzinie odpowiedniej, mianowicie w tej, któraby pozwoliła Mszę uroczystą tejże wigilii zaczać okolo północy pomiędzy W. Sobota, a niedzielą Zmartwychwstania.

Gdzie jednak - po rozważeniu warunków miejse i wiernych, na podstawie decyzji Ordynariusza - wypadnie antycypowlać odprawianie wigilii, to nie wolno jej zaczynać przed zmicrzchem dnia, w żadnym razie przed zachodem słońca.

\section{Wstrzymanie się od mięsa i post do pólnoey W. Soboty}

10) Wstrzymanie się od mięsa i post w okresie W. Postu, które dotą według can. $1252 \S 4$ w W. Sobotę kończyły się po południu, w przyszłości będą się kończyły o północy tej samej W. Soboty.

Bez względu na wszelkie inne przeciwne zarządzenia.

Dnia 16. XI. 1955.

(-) C. Kard. Cicognani, Swiętej Kongregacji Obrzędów Prefekt .

I. S.

(-) † A. Carinci, Abp. Seleuc. Swiętej Kongregacji Obrzędów Sekretarz

\section{N S T R U F $\boldsymbol{J}$ A \\ O NALEZYTYM ODPRAWIANIU WZNOWIONEGO PORZAQDKU WIELKIEGO TYGODNIA}

Cel wznowionego Porządku W. Tygodnia polega na tym, by wierni z większą łatwością, pobożnością i skutecznością mogli brać udział w czcigodnej liturgii tych dni przywróconej na ich właściwie i równocześnie odpowiednie godziny. $\mathrm{Z}$ tego powodu jest ważną rzecza, by ten zbawienny cel został w pełni osiagnięty. 